\title{
Paul Kammerer and epigenetics - a reappraisal of his experiments
}

\author{
Michael Nahm \\ Chair of Forest Growth and Dendroecology, Albert Ludwigs-University Freiburg, \\ Tennenbacher Str. 4, 79106 Freiburg, Germany \\ Institute for Frontier Areas of Psychology and Mental Health, Wilhelmstr. 3a, \\ 79098 Freiburg, Germany \\ Michael.Nahm@iww.uni-freiburg.de
}

\begin{abstract}
During recent years, the scientific interest in the work of Austrian biologist Paul Kammerer (188o-1926) has risen again. This development can largely be attributed to advances in the fields of epigenetics and epigenetic inheritance, and it resulted in provocative discussions. This article contributes to enhancing the knowledge about Kammerer's publications in two respects. First, I provide a brief overview and contextualization of Kammerer's main works on phenotypic plasticity and its inheritance, some of which seem little known at present. Thereafter, to ensure an accurate transmission of the historical record, I comment on recently published suggestive information about what Kammerer did and wrote, chiefly referring to Kammerer's original writings on fire salamanders (Salamandra salamandra) and cave salamanders (Proteus anguinus). Although the exact contents of Kammerer's writings remain controversial and must be regarded with caution, his writings need to be treated objectively and accurately to avoid historical record distortion and to render the performance of adequate replications of his experiments possible.
\end{abstract}

\section{Keywords}

cave salamander - fire salamander - historical record distortion - Midwife toad - Paul Kammerer - replication

\section{Introduction}

During recent decades, the interest and the knowledge regarding phenotypic adaption to environmental change and epigenetics have increased enormously. These discoveries also sparked 
renewed interest in the writings of controversial Austrian biologist Paul Kammerer (1880-1926), who was a major proponent of the theory of the inheritance of acquired characteristics in the first decades of the 2oth Century (Koestler, 1971; Hirschmüller, 1991; Taschwer, 2016; Gliboff, 2018; for treatises demonstrating this renewed interest in Kammerer see e.g., Gliboff, 2005, 2006, 2010; Logan, 2007; Pennisi, 2009; Vargas, 2009; Svardal, 2010; van Alphen \& Arntzen, 2016, 2017; Vargas et al., 2017; Sanchez et al., 2019). Kammerer's work is also referred to in more general publications on the potential significance of epigenetic inheritance for evolution (Jablonka \& Lamb, 20o6; Jablonka \& Raz, 2009; Liu, 2011). Whilst these recent publications addressed Kammerer's work on historical and theoretical grounds, others have also picked up the approach to replicate some of his work in practice again (Sanchez et al., 2019). Kammerer's career and the credibility of his writings were substantially damaged when it was discovered in 1926 that an alleged nuptial pad of a Midwife toad had been purposefully manipulated (Noble, 1926). He committed suicide a few months later. These incidences terminated what Gliboff (2011) termed "The Golden Age of Lamarckism". The inheritance of acquired characteristics sensu strictu was not incorporated into the emerging neo-Darwinian model of evolution as formulated in the Evolutionary Synthesis (Mayr, 1982). Nevertheless, the precise circumstances of the discovery of Kammerer's potential fraud and the developments that led to his suicide remained as enigmatic as the colourful biologist's personality itself, and kept the interest in him alive on a different plane than mere epigenetics and biological experimentation. Already Arthur Koestler (1971) raised doubts concerning the contention that Kammerer performed the fraudulent manipulations himself, and pointed to the possibility that he might have been a victim of purposeful sabotage. This notion was substantiated by recent investigations by Klaus Taschwer, who specialized in elucidating anti-Semitic movements in Vienna and its university (Taschwer, 2016; Gliboff, 2018; see also Hirschmüller, 1991).

With regard to a book the contents of which foreshadowed Carl Gustav Jung's concept of synchronicity (Koestler, 1971), Kammerer imparted that the future may ultimately judge his work as it approaches "the great filter of time" (Kammerer, 1919a, p. 15; all translations of German text in this article were performed by the author). Given the mentioned advances in epigenetics, the potential to apply an appropriate filter to Kammerer's work seem more promising than before. An important prerequisite for a proper re-assessment and recognition of Kammerer's work lies, however, in accurately understanding and interpreting his publications. For this purpose, the present article aims at providing a very brief overview on Kammerer's main works (some of which appear not well known) along with a contextualization, and most importantly, at clarifying and correcting recent contributions that presented misleading and even substantially wrong information about his writings, in order to bypass historical record distortion and to facilitate proper replications of Kammerer's experiments. In this context, it is not my aim to vindicate or rehabilitate Kammerer's work, but to set the record straight to allow for an impartial assessment of the matters. As pointed out by previous authors, one cannot believe all of Kammerer's claims (e.g., Bateson, 1913; Herbst, 1919, 1924; van Alphen \& Arntzen 2016, 2017), and Richard Goldschmidt (1956), Alma Mahler-Werfel (196o) and Karl von Frisch (see Taschwer, 2016, p. 144) commented critically on Kammerer's modes of experimenting and record keeping. But still, some of his publications addressed fascinating research questions 
that deserve attention in the light of the above mentioned developments in evolutionary and experimental biology.

\section{A brief overview and contextualization of Kammerer's main works}

In 1887 , about 28 years after Charles Darwin's (1859) seminal publication On the Origin of Species by Means of Natural Selection, zoologist August Weismann began a famous biological experiment that strongly influenced the development of biological thought: $\mathrm{He}$ cut the tails of mice for 22 subsequent generations (Weismann, 1892, 1904). Because their offspring was always born with tails of normal length, his experiment is often regarded as a refutation of Lamarck's (1809) theory of the inheritance of acquired characteristics. Darwin himself had been one of the most prominent promoters of this concept and developed the first theoretical model to describe possible pathways of the transmission of traits acquired by an organism, his model of "pangenesis" (Darwin, 1868). However, Weismann merely disproved the ultra-Lamarckian notion of Darwin, who deemed it possible that passively acquired injuries or mutilations can be heritable (Darwin, 1868) - something that Lamarck, who postulated the inheritance of actively acquired adaptions caused by the use and disuse of body parts, had never suggested. Because Weismann's findings and other arguments neither disproved Lamarck's nor Darwin's theory of the inheritance of acquired characteristics as a whole, numerous biologists regarded the reduction of evolutionary theories to genetic variation plus selection too simplistic and continued to consider the inheritance of acquired characteristics possible.

Among these biologists were Berthold Hatschek, Richard Wettstein and Karl Przibram, who were instrumental in establishing the Biologische Versuchsanstalt in Vienna in 1902. In fact, it was regarded a specific task of this institution to address questions concerning environmental influence, ontogenetic development, and evolution via launching a comprehensive experimental program. Soon after, Kammerer and other researchers began to put this into practice, thus spearheading the approach of conducting long-term experimental studies with living animals that were already at that time deemed hardly possible in a university setting (Feichtinger, 2017; Müller, 2017). Especially Kammerer's publications were regarded critically by peers (e.g., Bateson, 1913; Baur, 1914a, 1917; Megušar, 1914; ${ }^{1}$ Werner 1915; Boulenger, 1917; Herbst 1919, 1924). They complained that his theoretical reasoning appeared prejudiced and misleading, and that he presented the results of his practical experiments in such a sloppy way that it remained

1 Megušar's criticism of his colleague Kammerer must be regarded with caution, however. Apparently, Megušar had a fierce personal aversion against Kammerer (Przibram, 1926) and may even have considered ways of getting rid of him (Iltis in Taschwer, 2016, p. 144). In fact, Megušar's claim that the larvae of fire salamanders he used in his experiments did not turn dark on dark background and light on light background (thus contradicting Kammerer), is at odds with the results of everybody else who ever performed such trials under appropriate experimental conditions (see further below in the text). According to Megušar's supervisor Hans Przibram, his experiments were "inapt" (Przibram in Hirschmüller, 1991, p. 42) and performed under insufficient light conditions. Perhaps also for other shortcomings, Megušar's report on this experiment was not deemed worthy of publication (Przibram with Dembowski, 1922). In addition, Megušar must have suffered from mental confusion around the time he launched his attack on Kammerer and was transferred to an asylum shortly after (Przibram, 1917, 1926; Przibram with Dembowski, 1922; Wettstein in Hirschmüller, 1991, p. 42). 
hard to fully understand which material he worked with, how precisely the experimental conditions were applied, and how exactly the results were obtained.

In fact, Kammerer worked with a considerable number of animal species, and it might well have been difficult for him to establish, document and describe all of these experiments in necessary detail. Apart from studies Kammerer pursued with regard to for example regeneration (e.g., Kammerer, 1907a, b) and symbiosis (e.g., Kammerer, 1907c, 1913a), he performed experiments in the context of phenotypic modifications in response to experimentally altered environmental conditions. He exposed Alpine salamanders (Salamandra atra) and fire salamanders (Salamandra salamandra) to substrates of different colour and moisture content, and in general, the animals seemed to react to these stimuli by becoming darker on dark and dry substrate, and brighter on yellow and moist substrate (Kammerer, 1911, 1913b). Inspired by these results, he attempted to induce colour adaptions also in other animals such as slugs (Deroceras agrestre and Limax cinereo-niger), the Roman snail (Helix pomatia), the great crested newt (Triturus cristatus), fire-bellied toads (Bombina bombina and B. variegata), toads (Bufo bufo, Bufotes viridis, Epidalea calamita, Pelobates fuscus), frogs (Rana dalmatina, R. temporaria, and Pelophylax kl. esculentus) (Kammerer, 1910a, 1911), as well as in at least 18 species of lizards plus species of the Scincidae (Kammerer, 1910b, 1911). In general, also these animal species responded to the applied stimuli in varying degrees, but with the exception of some Southern European and desert species of lizards which remained largely unchanged.

In some of the tested animals, Kammerer also obtained successor generations. The fire salamanders exposed to differently coloured backgrounds represent a famous example (Kammerer, 1911, 1913b). Only in these prolonged experiments, the inheritance of acquired characteristics came into play. According to Kammerer, salamanders reared on yellow background became more yellow than individuals raised on black background which turned darker, and these traits were transmitted to their offspring. Correspondingly, he reported that also the offspring of crested newts that were raised on yellow soil tended to be lighter than usual. The situation was more difficult in toads and frogs, as their capability to display reversible and physiologically driven colour changes interfered with the establishment of a distinct and durable colour change. Only when reared continuously in the same-coloured environment for more than one generation would a reasonably stable colour adaption eventually become discernible (Kammerer, 1911). In the lizard species that produced offspring, induced colour changes were also heritable to a certain degree (Kammerer, 1910b).

Kammerer tested also the heritability of other phenotypic modifications in response to experimentally altered environmental conditions, especially reproduction strategies. For example, he reported that viviparous Alpine salamanders would turn to giving birth to smaller and more numerous larvae with gills when forced to staying in unusually moist environments or even in shallow water for four periods of pregnancy; and vice versa, ovoviviparous fire salamanders would become viviparous when access to water was denied. The offspring of salamanders born under these conditions still showed these adaptive traits in diminished degrees, thus demonstrating their heritability (Kammerer, 1904, 1907d). Similarly, Kammerer reported that females of ruin lizards (Podarcis siculus) laid eggs with increasingly 
hard and thick shells when kept under unusually high temperatures, and offspring from these eggs laid eggs with harder shells than usual even when reared under normal temperature conditions. Furthermore, females of the viviparous lizard (Zootoca vivipara) kept at unusually high temperatures also turned to laying eggs with a thin parchment-like shell (Kammerer, 1924). Following initial experiments on rearing offspring of the Midwife toad (Alytes obstetricans) and tree frogs (Hyla arborea) under different environmental conditions (Kammerer, 1906), Kammerer continued to work with Midwife toads. For example, he forced individuals of this land-breeding species to live in unusually high temperatures, and these individuals turned to reproducing in water as a response. This accommodation resulted in various modifications of the eggs, but also of instincts and the morphological appearance of adults, especially in later generations (Kammerer, 1909, 1919b). A prominent example was the development of nuptial pads in adult males, which later resulted in the fraud scandal already mentioned. ${ }^{2}$ Kammerer furthermore experimented with generations of sea squirts (Ciona intestinalis) and assessed their ability to regrow removed siphons as well as gonads. He reported heritable siphon modifications (Kammerer, 1923a, b). Moreover, he exposed rats to unusually high temperatures. Male rats displayed anatomical changes in their testicles that were heritable (Steinach \& Kammerer, 1920; see also Przibram, 1910a, 1925). Another well-known publication of Kammerer refers to his experiments with European cave salamanders (Proteus anguinus). He reported that individuals kept in red and reduced amounts of light grew considerable eyes, in contrast to their normal development in the dark. However, he didn't grow successor generations of such cave salamanders (Kammerer, 1912).

In the context of Kammerer's transgenerational experiments, the distinction between "direct induction" and "somatic induction" as outlined by Carl Detto (1904) was crucial. In the first case, environmental stimuli such as increased temperatures would directly affect an organism's germ line, resulting in the production of modified offspring - a process that also Weismann and his followers accepted. In the second case, only the soma would be affected by environmental stimuli, then transmitting respective signals to the germ cells, thus constituting the inheritance of acquired characteristics proper. Detto himself was critical of its occurrence, and also cautioned it would always entail some form of vitalism, which he rejected. Indeed, "psycholamarckian" concepts as proposed by August Pauly (1905) bore a distinct vitalist notion. Around the same time, experimental biologist Hans Driesch published influential treatises in which he explicitly promoted neo-vitalist concepts (Driesch, 1903, 1908).

Kammerer's work was settled amidst these different lines of biological thought. In his transgenerational experiments, he aimed at finding conclusive evidence for somatic induction without resorting to vitalism. Stating that scientific progress was most efficient when regarding life as an extraordinary complex manifestation of physicochemical nature and applying

2 Kammerer noticed the seemingly unexpected presence of these dark pads only on males of the fourth generation, and didn't consider them a crucial outcome of his experiments (Kammerer, 1919b, 1923a). Years after the experiments, herpetologist Gladwyn Kingsley Noble examined the left hand of the only remaining specimen of Midwife toads with nuptial pads, and noticed that it was conspicuously manipulated by the injection of black ink (Noble, 1926; for an overview on the entire affair, see Koestler, 1971. The ink was not injected into "the forelimbs" of "a few of his specimens" as stated by Coen, 2006, p. 512). Moreover, Indian ink was apparently also injected into preserved specimens of fire salamanders that had lived on black background (Anonymous, 1926). 
a respective research approach (Kammerer, 1915), he adopted a pragmatic and positivist stance - a view also promoted and elaborated by later authors associated with the Biologische Versuchsanstalt who developed systemically orientated "organicist" theories and remained critical of neo-Darwinian concepts, most notably Ludwig von Bertalanffy (1928, 1970; see also Nahm, 2021). Experimental studies performed elsewhere by other researchers also concerned the issue of direct vs. somatic induction, assessing extra-nucleic hereditary factors that would result in a Dauermodifikation (Jollos, 1921) or Dauerinduktion (Woltereck, 1932). However, comparable research questions only gained renewed momentum with the advent of modern epigenetics, entailing novel keywords and often overlapping concepts such as parental effects (Badyaev \& Uller, 20o9), non-genetic inheritance (Danchin et al., 2019), epigenetic inheritance (Burggren, 2016), soft inheritance (Richards, 2006), as well as developmental and/ or phenotypic plasticity (West-Eberhard, 2003). In relation to these contexts, and regardless of their ultimate trustworthiness, Kammerer's experiments with cave salamanders that grew eyes and with Midwife toads that grew nuptial pads might tie in with experimentally induced atavisms (Cabej, 2019, Chapter 12), and his experiments addressing shifts of reproduction strategies of amphibians and lizards with similar, but comparably moderate and short recent trials (Ma et al., 2014; Sun et al., 2018).

Some of Kammerer's transgenerational experiments with lizards might also find refreshed interest in the context of speciation. As mentioned, he reported that some of the environmentally induced changes were heritable (Kammerer, 1910b, 1924), and he postulated that such processes would also contribute to the formation of different kinds of lizards, e.g., on Dalmatian islands (Kammerer, 1926). In the same area, Vervust et al. (2007) and Herrel et al. (2008) described remarkable and seemingly heritable evolutionary changes of morphological and behavioural traits in a population of lizards on an island that occurred only within ca. 30 generations after separation from their source population living on an island with a different habitat structure. Some of the described changes resemble differences of subspecies of lizards described by Kammerer (1926), and which he attributed to comparable differences in the islands' habitat structure. Morphological and behavioural alterations in lizard populations facing new environmental challenges are seemingly conveyed via alterations of the methylation patterns in their genome (Paredes et al., 2016; Schrey et al., 2016, see also Shine \& Downes, 1999). Hence, the findings of Vervust et al. (2007) and Herrel et al. (2008) might well be attributed to epigenetic inheritance as well, and might represent a first step for subsequent speciation, thus supporting Kammerer's view (compare Smith et al., 2016). In any case, modern trends in evolutionary biology reinforce the notions of the founders of the Biologische Versuchsanstalt who maintained that the focus on genetic variation and selection as the main driver of evolution was too narrow (Müller, 2017). Recent findings open a huge array of further experimental and theoretical inquiry into evolutionary biology, in which also Kammerer's (1913a) pioneering emphasis of co-operation and symbiosis finds its place, such as in the "extended evolutionary synthesis" (Laland et al., 2015; Jablonka \& Lamb, 2020), the "integrative synthesis" (Noble, 2017), and the "inclusive evolutionary synthesis" (Danchin et al. 2019).

\section{Clarifications and corrections of recent publications about Kammerer}

The fact that Kammerer's detailed publications are only available in German and 
that his English summaries are sometimes unduly short and ambiguous can easily lead to misunderstandings regarding his work. For example, Vargas (2009) thought that major adaptions in water breeding Midwife toads reported by Kammerer developed in subsequent generations of toads that were exposed to the relevant stimuli, but in fact, they developed in the offspring of the same generation of parents that was continuously exposed to the relevant stimuli for several reproductive cycles (see Gliboff, 2010; Svardal 2010, but also Vargas et al., 2017). Similarly, Baedke (2019) wrote that when mothers and offspring in fire salamanders were prevented from accessing water, more completely developed larvae with lungs and legs were born after four generations. However, also these changes were induced in the offspring of the same parent generation after exposing these animals to the relevant stimuli for four to six reproductive cycles (Kammerer, 1904). Kammerer also obtained one F2-generation after offspring of the later reproduction cycles had become sexually mature. He reported that the acquired traits had been inherited (Kammerer, 1907d). In the following sections, I first comment on a lately performed experiment with fire salamanders that is supposed to have confirmed Kammerer's (1913b) experiments on the skin colour adaptation of these animals (Sanchez et al., 2019). Thereafter, I will remark on suppositions contained in a critical publication on Kammerer and his work (van Alphen \& Arntzen, 2016), and briefly turn to these authors' second publication (van Alphen \& Arntzen, 2017).

\section{Comments on recent experiments with fire salamanders}

In a stimulating approach, Sanchez et al. (2019) attempted to repeat Kammerer's experiments to induce skin colour modifications in fire salamanders in the context of assessing 1) the potential role of their skin coloration as an aposematic signal and 2) their skin toxicity. They stressed that Kammerer's experiments needed to be replicated in practice rather than being reanalysed or reinterpreted on theoretical grounds, and they succeeded in confirming the reported effect: When larvae were kept on yellow background, the proportion of yellow skin of metamorphosed salamanders was significantly larger than when reared on black background ( $\mathrm{p}<$ o.oo1). Nevertheless, the references to Kammerer's original work provided by the authors are not always accurate. For example, they claim that Kammerer's interpretation of the results was "at least partially wrong" in that he assumed "that the yellow color (wavelengths) was somehow trapped into the salamander skin" (Sanchez et al., 2019, p. 32). Kammerer never made such a claim. Rather, he had a twofold and quite different explanation for the induced colour change in salamander skin pigmentation: First, it involved the photoreceptors of the animals' eyes and the central nervous system as their skin would remain largely unaffected in blinded individuals or in darkness; and second, it involved an independent sensitivity of the skin to moisture: Moist environments enhanced the yellow proportions of the skin whereas dry conditions enhanced the black proportions (Kammerer, 1913b). Sanchez et al. (2019) furthermore stated that Kammerer used yellow and black backgrounds in his experiments, and presented their use of a third variant (using a grey background) as an innovation to address the question whether potential colour changes would be due to the background colours themselves or merely due to their albedo. However, Kammerer had in fact addressed a very similar question already. In order to discern the roles that the colours themselves may play in comparison 
to the light intensity (which is related to the albedo), Kammerer (1913b) used also red, green, blue, violet, brown, white, and also grey backgrounds. In addition, he also employed differently coloured transparent coverages (Kammerer, 1922). Kammerer concluded that both the quality and the quantity of the applied light are relevant for inducing an observable colour change. ${ }^{3}$

More importantly, it is essential to understand the details of Kammerer's experimental approach and also their historical context in order to replicate Kammerer's experiments in an appropriate way. Strictly, speaking, the appraisal of Sanchez et al. (2019) that they "replicated his experiment, and independently obtained the same basic outcome" (p. 33), and that they confirmed that "exposure of fire salamander larvae would "induce long-lasting color changes that are carried-over after metamorphosis" (p. 32) is not wholly adequate for two reasons. In contrast to their assertions, the reported "carry-over effect" was not described by Kammerer - simply because Kammerer didn't work with larvae in the decisive initial stage of his famous series of experiments, but with salamanders that had already undergone metamorphosis a few months or about one year ago. ${ }^{4}$ According to Curt Herbst (1919), a close friend of Hans Driesch, this difference is of vital importance: Whereas larvae are able to perform significant physiological colour adaptions (see also Flemming, 1897, and compare Polo-Cavia \& Gomez-Mestre, 2017) that result in according skin colour dominance also after metamorphosis, salamanders that metamorphosed already one year ago are likely to possess only a comparably limited ability to adapt to environmental colours. For the same reason, Herbst (1924) claimed that even working with freshly metamorphosed salamanders as von Frisch (1920) did in some of his test series would constitute a different approach than working with one-year old individuals, and hence, such experiments could not be regarded as replications of Kammerer's experiments. Nevertheless, several authors who aimed at repeating Kammerer's experiments did indeed work with larvae from the beginning. In all studies, the colour adaption of the salamander larvae was still recognizable after metamorphosis, and the degree of this adaptation was also considerably enhanced in comparison to Kammerer's experiments, in which the salamanders needed years to reach a comparable stage (Šećerov, 1914; Herbst, 1919; von Frisch, 1920; Boulenger, 1921; Przibram with Dembowski, 1922). However, Kammerer's colleagues Šećerov (1914), von Frisch (1920), and Przibram with Dembowski (1922) had a mere intragenerational research focus and stopped their experiments not long after the metamorphosis of their larvae.

Herbst (1919, 1924) criticized their experiments because they would not allow for decidedly concluding that they confirmed Kammerer's findings. In several test series, Herbst obtained remarkable colour adaptions

3 Also Herbst (1919) used already a blue background in addition to black and yellow in his experiments. It was slightly darker than the yellow background. Accordingly, larvae living in the blue environment were on average slightly darker than those living in the yellow environment, but both were considerably lighter than those living in black environment. These results seem well in line with the findings of Sanchez et al. (2019), but Herbst didn't follow the development of the salamanders living on blue background after their metamorphosis. And, like Kammerer, also Herbst (1919) and von Frisch (1920) experimented with white backgrounds already. Šećerov (1914) performed photometric measurements of the light reflected by the yellow and black backgrounds he used (i.e,. their albedo), and suggested that the resulting differences in light intensity might induce the observed colour adaptions.

4 Only after other authors had already worked successfully with larvae, Kammerer (1913b) also kept larvae of the F2-generation in black and yellow environments (see also Sanchez et al., 2019, p. 33). 

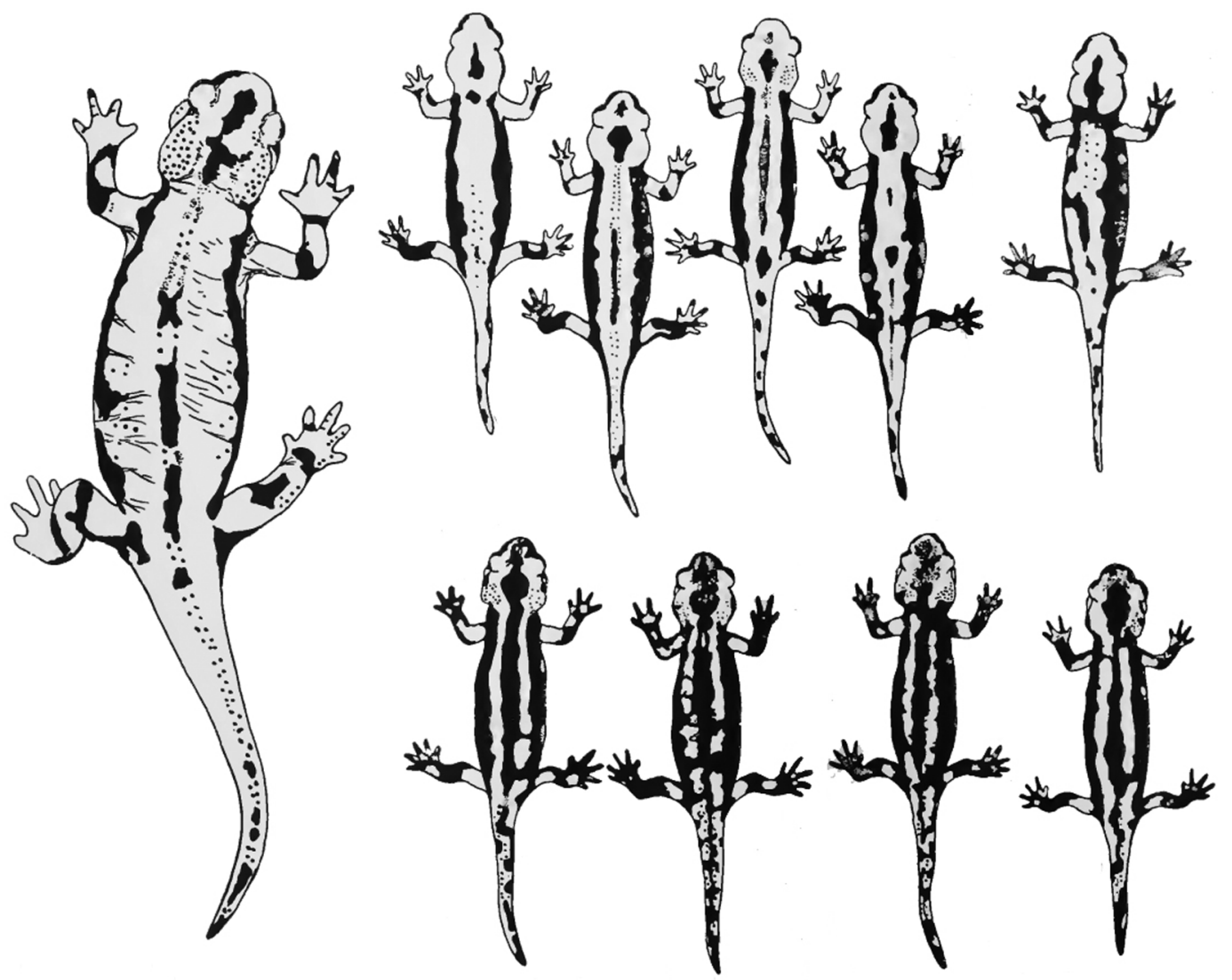

FIGURE 1 Examples of fire salamanders (Salamandra salamandra) kept on yellow and black backgrounds.

The animals belong to one of the many series documented by Curt Herbst (1919; excerpt of Plate II; digitally revamped by M. Nahm). Left: The mother of the nine smaller individuals on the right. Top: Five salamanders reared on yellow background since being larvae; bottom: Four specimens reared on black background since being larvae. It is obvious that the animals kept on yellow background are lighter in colour

in response to background colours in juvenile salamanders after metamorphosis as well (e.g., fig. 1). Yet, he found that the colour distribution on their skins would become largely decoupled from the colour of the environment in later stages of their lives and would counterbalance the initial adaptation effect, being increasingly determined by genetic factors. After years of continuous exposure to yellow and black backgrounds, the salamanders would not show the initial effect any more, and thus contradict Kammerer's reports of increasing colour adaption (Herbst, 1919, 1924; e.g., fig. 2). Apart from Herbst and
Kammerer, it seems that only Boulenger and MacBride let their joint experiment run for a prolonged period of time. Of this latter trial, however, only three individuals were alive after four and a half years, and MacBride described only the skins of two of them (MacBride, 1925). For a number of reasons, Herbst didn't consider MacBride's report reliable (Herbst, 1927). On the other hand, Herbst's own results were later supported by experiments performed by Fernandez and Collins (1988) with Arizona tiger salamanders (Ambystoma tigrina nebulosum). Initially, their skin strongly responded to the 

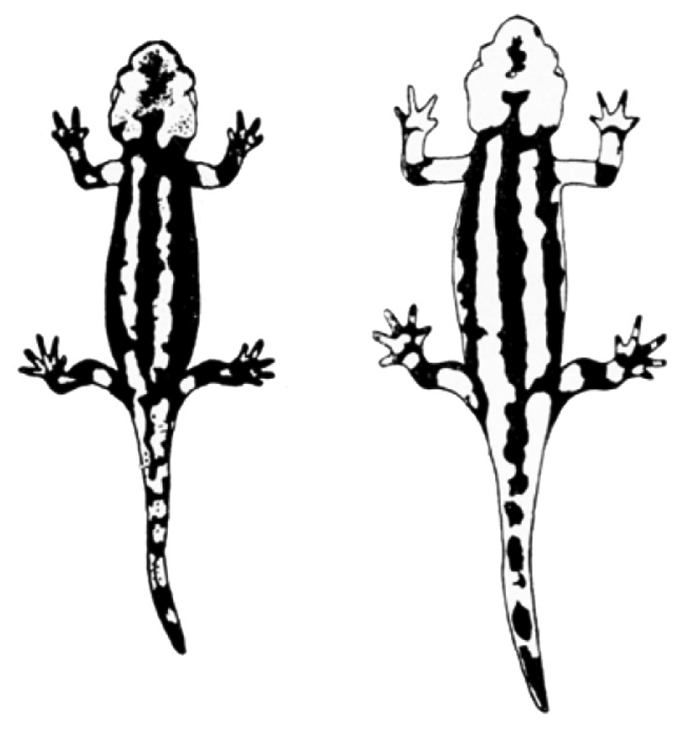

\section{A}
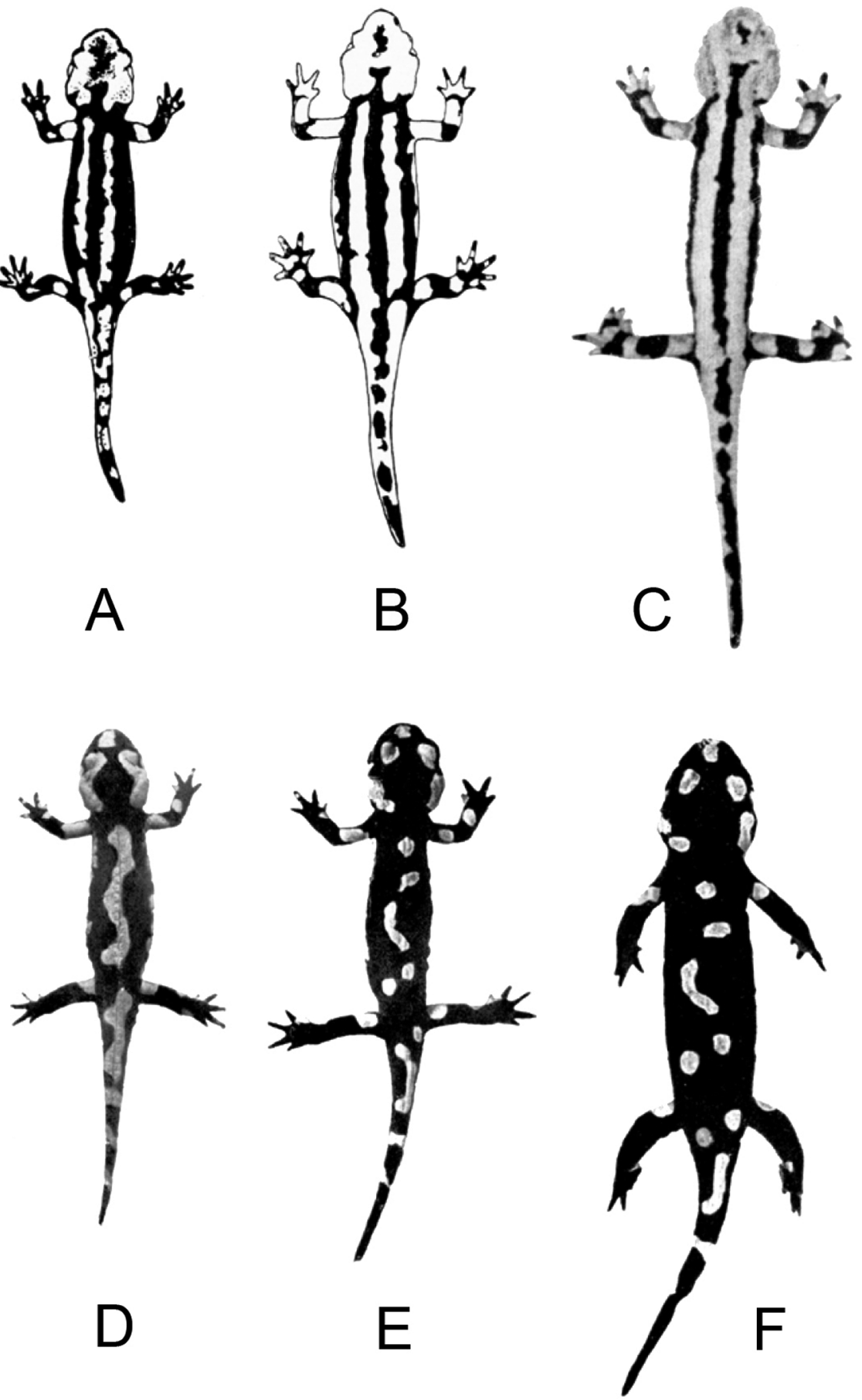

FIGURE 2 Example of the spot distribution development in a salamander individual (the second individual from the right in the bottom row shown in fig. 1). The salamander was continuously kept on black background, but still became progressively yellow, increasingly resembling its mother. Documentation dates of A, B, and C: 29.06.1917, 28.og.1918, and 10.10.1922. D, E, F: Example of the development of a specimen continuously kept on yellow background. Nevertheless, it turned increasingly dark. Documentation dates of D, E, and F: 13.06.1918, 12.09.1919, and 21.09.1921.

SOURCES: A, B, AND C REPRESENT FIG. 21 IN HERBST (1924); D, E, AND F REPRESENT FIG. 10 IN HERBST (1924); воTH ARE DIGITALLY REVAMPED BY M. NAnh 
exposition of black and white environments, but with age, the animals became lighter in colour regardless of the substrates' colour. Hence, because Sanchez et al. (2019, p. 28) terminated their experiment already "approximately 30 days or 98 days" after metamorphosis, their results are open to the same criticism that Herbst $(1919,1924)$ addressed at his contemporary fellow researchers who claimed having replicated Kammerer's initial experiments, but seemingly terminated their experiments too early after the metamorphosis of their salamanders (Šećerov, 1914; von Frisch 1920; Przibram with Dembowski, 1922). In a proper sense, Sanchez et al. (2019) only repeated and confirmed the experiments of the latter authors, and only the initial stages of those performed by Herbst (1919, 1924) as well as by Boulenger and MacBride (Boulenger, 1921; MacBride, 1925). It thus appears premature to state that their experiment would have resulted in "long-lasting color changes" as reported by Kammerer. In order to justify such a statement, the metamorphosed salamanders must be observed at the very least for six months, and to arrive at reliable conclusions, for at least one or two years (Herbst, 1919).

Hence, the crucial and still remaining questions with regard to repeating Kammerer's experiments are still open: Do the induced colour adaptions persist and propagate in adult salamanders, and are they heritable? In experiments with amphibians designed to properly repeat Kammerer's trials, it is therefore vital to let them run for a much longer period of time - as Sanchez et al. (2019) recommend themselves - and to know the historical literature in order to avoid repeating (potential) pitfalls that previous researchers had stepped in already hundred years earlier. Nevertheless, the approach of Sanchez et al. (2019) constitutes a valuable and encouraging practical step in the right direction.

\section{Comments on recent criticisms of} Kammerer's work

Recently, van Alphen and Arntzen (2016, 2017) advanced critical assessments of Kammerer's work and publications. Some of their arguments compellingly highlight problematic aspects of Kammerer's writings, for example his report on the incidence of cave salamander reproduction and of viviparity in naturally occurring fire salamander populations in Central Europe. Yet, many arguments of van Alphen and Arntzen represent mere speculations, and yet again, several points they made are simply wrong. It follows that to prevent the transmission of wrong claims about Kammerer and his work in the potential future downstream literature, the record needs to be corrected again. In the next sections, I focus on van Alphen and Arntzen's first publication (2016).

\section{Colour adaptions of fire salamanders}

In their section titled "The evidence", van Alphen and Arntzen (2016) first highlighted that Kammerer hand-coloured his photographs showing representative salamander specimens in his publications, and also retouched some of them. They stressed that editing photographs in this manner wouldn't improve their value as scientific evidence. This is true, but presenting (hand-coloured) drawings in scientific articles was a usual practice in biological journals of this time. Consequently, manual corrections or retouches of photographs shouldn't be regarded a bigger problem (Gliboff, 2005). Because it was apparently difficult to produce high-quality photographs of salamanders about 100 years ago, many authors who worked with them presented drawings, sometimes being hand-coloured (e.g., Šećerov, 1914; Herbst, 1919; von Frisch, 1920; Boulenger, 1921; Przibram with Dembowski, 1922; MacBride, 1925; Herbst \& Ascher, 1927; Noble, 1931). More 
importantly, the 19 salamander photographs contained in Kammerer (1911) were not handcoloured at all, and only six were "slightly" retouched. All 19 photographs are included again in Kammerer's main work on fire salamander colouration (Kammerer, 1913b). Now, they were hand-coloured indeed, highlighting the visibility of the specimens' colour patterns. However, with one exception, it is obvious on close inspection that the coloured spots neatly correspond to the visible spots in the original photographs, thus providing no reason for suspicion and tampering. ${ }^{5}$ Moreover, the head of the Biologische Versuchsanstalt, Hans Przibram, reported that members of the Vienna university performed an examination of the images in comparison to the conserved original specimens, and found nothing to complain about (Przibram with Dembowski, 1922). Because Kammerer also included drawings of salamanders in his publications, van Alphen and Arntzen continued as follows (p. 463):

Likewise, the drawings can hardly be considered as evidence for his results. As an example we use the plates in Kammerer (1910) representing salamanders kept on black or yellow paper (Plates III and IV). They show individuals at the beginning of the treatment and, as he writes in the accompanying figure caption: "the same specimen after 4 years". They would constitute the evidence that salamanders kept on yellow paper become more yellow, and those kept on black paper blacker. Baur (1914b) objected to the retouching of the photographs and pointed out that not only the spot size, but also the colour patterns had become different after four years, and therefore could not involve "the same specimen". [...] Kammerer admits in his reaction "That they are not the same animals is evident from their different colour patterns" but he downplays that fact and apologizes for using the words "the same specimen": "I admit that the text used in the caption can be misunderstood, and thank Prof. Baur for providing me the opportunity to confirm that explicitly." (Kammerer, 1914a, p. 684). But there is really no question of misunderstanding, the same specimen is not a different specimen! It cannot be denied that Kammerer was dishonest in that quote.

However, the Kammerer (1910) publication is missing in their references list, it is also not contained in Baur's (1914b) and Kammerer's (1914a) dialogue about the critical figure caption, and to my knowledge, a 1910 publication of Kammerer that contains "drawings" of salamanders on Plates III and IV doesn't even exist. It must be assumed that the authors meant to cite the already described Kammerer (1911) publication. This publication contains a Plate III and a Plate IV, but as mentioned, they comprise mostly unedited photographs, not drawings. Moreover, of the 19 photographs displayed, only four photographs on Plate III depict salamanders "kept on black or yellow paper." According to Kammerer, they are unedited. In addition, Baur (1914b) referred to Kammerer's main fire salamander treatise (Kammerer, 1913b) in his comment, not to Kammerer's previous treatise (1911), as van Alphen and Arntzen seem to suggest.

Above all, their claim that the accompanying figure caption would include the phrase "the same specimen after 4 years" is false. In literal translation, the relevant parts of the

5 This exception concerns Fig. 1a on Plate III in Kammerer (1911) and Fig. 26 on Plate XV in Kammerer (1913b). Both show the same image, but according to the figure captions, they belong to different experimental series. However, Kammerer (1913b) already pointed to an apparent confusion of the two images. Consequently, also this inconsistency cannot be regarded as evidence purposeful tampering. 
figure caption given by Kammerer (1911, p. 288) read as follows: "All Figures are photographs. [...] Documentation exemplars in possession of the [...] museum of the Biologische Versuchsanstalt in Vienna. [...] a) Initial state of the trial, b) after four years of keeping on yellow paper [or black paper, respectively]." Although these formulations are ambiguous and can indeed raise the impression that the two salamander images are supposed to show the same specimen, a closer look on their colour patterns shows that this can hardly be the case. Furthermore, a salamander that has already been killed and preserved as an exemplar for documentation in the museum of Kammerer's research station cannot live for four more years and change its spots.

Still, van Alphen and Arntzen proceeded to claim that Baur (1914b) had objected to Kammerer's allegation that the photographs in question display "the same specimen". Yet, also the relevant figure captions for the reprinted and coloured photographs in Kammerer (1913b), the source that Baur actually referred to, don't contain the phrase "the same specimen." Rather, although the wordings of the figure legends are imprecise and ambiguous in this publication as well, they also comprise formulations signifying that the shown specimens are in fact not the same. For example, Plates II to XIII in Kammerer (1913b) are each explicitly introduced by the author as showing "one and the same specimen" during different stages of development (p. 191). These Plates contain drawings that obviously do concern the same individuals. In contrast, the successive Plates XIV and XV - the ones containing the critical salamander photographs Baur referred to - are only supposed to show "characteristic initial and final stages" of experiments with the purpose to complement the drawings displayed on Plates II to XIII (p. 192). Plates XIV and XV contain six image pairs that are relevant in the present context, and for one of them, Kammerer even added information about the sister of a salamander in the final stage, thus implying that the salamander showing the initial stage has no relation to this sister, and is a different individual indeed.

Hence, because Kammerer's never used the phrase "the same specimen" in legends describing the relevant photographs in his publications (Kammerer, 1911, 1913b), Baur (1914b) of course didn't accuse Kammerer of using this phrase. He merely alerted Kammerer that his ambiguous figure captions would raise the impression that the photographs concern the same specimen, but that they cannot belong to the same specimen on close examination. Kammerer (1914a) readily agreed with Baur and thanked him for pointing to the ambiguity of these captions. He stressed that the relevant pairs of individuals showed different specimen indeed, as evidenced by their colour patterns, and that they had already been displayed on exhibitions together and next to each other. Therefore, van Alphen and Arntzen's assertion that Kammerer played the use of the words "the same specimen" down and apologized for using them is mistaken. Consequently, their declaration that there would be "no question of misunderstanding, the same specimen is not a different specimen! It cannot be denied that Kammerer was dishonest in that quote" (p. 463) is false again and rests indeed on a peculiar misreading of the original literature on their part.

Furthermore, it is also incorrect that regarding the black to yellow ratio of the skins of his salamanders, Herbst (1924) "found only subtle changes in colour with age" (van Alphen \& Arntzen, 2016, p. 463). In addition to the colour changes with age, Herbst reported in fact quite significant influences of black and yellow environments on the skins of larvae and juvenile fire salamanders (Herbst, 1919; fig. 1). In general, and in contrast to van Alphen and Arntzen's claim that there is "no 
evidence" for colour changes in response to background colour in fire salamanders, there is substantial evidence for this response in larvae and juvenile salamanders, as I pointed out earlier in the discussion of the publication by Sanchez et al. (2019). Similarly, van Alphen and Arntzen's statement that "Balagova and Uhrin (2015) showed that spot size increased with size in $S$. salamandra from Slovenia, but not in response to background colour" (2016, p. 464) is misleading because these authors neither mentioned nor addressed possible influences of background colours on salamander spot sizes. Van Alphen and Arntzen also cited Bateson (1913) who found no transitions between the striped subspecies of Western European salamanders and the irregularly spotted one from Eastern Europe, what seems to support their "inescapable conclusion" that Kammerer used salamanders from different populations to suggest that offspring changed their spot distributions when placed on yellow or black backgrounds. However, such transitions are in fact known to occur naturally within certain regions and even local populations of fire salamanders (e.g., Najbar et al., 2018; Klewen, 1985).

Returning to Kammerer, it is a pity that he stopped his salamander experiments at a time they received much attention. In his own words, he was simply tired of experimenting with these animals already for 20 years, as well as of dealing with numerous difficulties in their keeping, the long time spans needed for their reproduction, and all the criticism he received. To avoid all this, he searched for organisms that were easier to keep in "pure lines", and he believed having found such an organism in Ciona (Kammerer, 1913b). Indeed, it seems Kammerer had so many other ideas and interests he urgently wanted to pursue that he simply didn't want focus on practical experiments with salamanders for much longer, as demonstrated by numerous articles and books on different biological topics he published in 1912 and 1913 (Taschwer, 2016).

\section{Viviparity in fire salamanders}

Van Alphen and Arntzen commented Kammerer's experiments on the reproduction mode of fire salamanders as well (Kammerer, 1904). For example, they had doubts regarding the veracity of Kammerer's results because the salamanders that were to be trained to give birth to more mature larvae on land "were denied access to water only when they were pregnant and close to giving birth" (van Alphen \& Arntzen, 2016, p. 465). However, this was not the case. Unfortunately, Kammerer is ambiguous in his description of the experimental design, but from what he has written on this particular detail, one can guess that he removed the water basins from the terrariums for longer time spans, perhaps even permanently. This is most evident in his major publication on this experiment (Kammerer, 1904), which also refers to an earlier source according to which salamanders that were forced to live exclusively on land for prolonged periods of time would have given birth to large and comparably far developed larvae with only short gills, soon entering metamorphosis (Bedriaga, 1897). Without specifying the precise moment, Kammerer proceeded to explain that he had "ultimately" [endgültig] removed the water basin for his experiments. In addition, he explicitly advised against placing individuals that are close to giving birth in terrariums without water, as the mothers and the offspring would often die. Rather, successful propagation of offspring was best obtained when their parents were still early in their pregnancy or not even pregnant at all when being placed in such terrariums. Subsequently, $80 \%$ of these individuals became used to reproducing without water. In any case, it is interesting to note that a subspecies of fire salamanders (Salamandra salamandra fastuosa) 
is known to have a mixed reproductive strategy, i.e., the females can give birth variously to larvae and metamorphosed juveniles. In this case, the number of fertilized and unfertilized eggs is variable, as is the size and the developmental stage of the larvae. More developed larvae may eat degrading unfertilized eggs and even smaller siblings, and all this can occur in the same female: They can alternatively bear numerous larvae or fully metamorphosed young (Greven, 2003). This suggests that the driving factors in regulating these pregnancies are under maternal control, and repeating experiments along the lines of Kammerers' might thus provide intriguing insights into the early developmental stages of viviparity when the reproductive mode is still plastic.

Van Alphen and Arntzen furthermore highlighted an alleged contradiction in Kammerer's description of the offspring of the parent generation. The relevant excerpt begins with a citation from page 227 of Kammerer's (1904) treatise:

"Two to three years, i.e., four to six pregnancies, are needed before the adaptation is completed and the offspring are born with either tiny functionless rests of the gills, or without gills, but the gill slits still open, or, finally, with closed gill slits as fully metamorphosed salamanders." He [Kammerer] continued to state (p. 227): "The viable larvae are born at an increasingly larger size and closer to metamorphosis, but are also produced in smaller numbers, while the rest of the clutch is retarded in its development and almost always crippled." In the conclusions at the end of the paper (p. 254) this becomes: "The intra-uterine conditions of such female $S$. maculosa that give birth late, resemble those of Salamandra atra: as only a reduced number of eggs develop into embryos, the large propor- tion of the eggs that do not develop turn into a mass of yolk that serves as food for the developing embryos." (Note the difference with the previous statement). VAN ALPHEN \& ARNTZEN, 2016, p. 464

In fact, there exists no discrepancy or contradiction between these statements. The first sentence cited by van Alphen and Arntzen refers to the birth of metamorphosed salamanders, the second sentence to the birth of larvae, and the third sentence to the birth of metamorphosed salamanders again. Perhaps the confusion of van Alphen and Arntzen was facilitated by their reversal of the order of the citations they used from p. 227 of Kammerer's (1904) publication. Kammerer's “continuation", i.e., the second sentence listed above, actually precedes the first sentence considerably in the original text.

\section{Kammerer's work on cave salamanders}

In this section, I'd like to comment on some of van Alphen and Arntzen's (2016) statements regarding Kammerer's experiments with European cave salamanders. The authors wrote (pp. 46of, 467):

Kammerer claimed that animals kept from childhood alternately in daylight and red light also developed larger eyes. These remained covered by the skin, but by removing the skin surgically, he claimed to have created a cave salamander with functioning eyes. This animal was preserved and when Kammerer visited Cambridge in 1923 he took the specimen with him. [...] In England this cave salamander was photographed and the picture is printed in Koestler's book (Fig. 2). The photo shows the front part of a dark cave salamander, with eyes clearly visible. [...] How did Kammerer come in the possession of a cave salamander 
with functional eyes? [...] He claims that the animal that he operated was born in his laboratory, and he provides no information on the origin of the parents. [...] In 1986 a black subspecies of the cave salamander was discovered in South East Slovenia, with normal functional eyes. [...] It is at [sic!] astonishing that Kammerer was aware of cave salamanders with well-developed eyes such as P. a. parkelj. [...] He may have stumbled upon the find on a trip to Postonja cave [...], or bought it on the market in Triest $[\ldots]$ on his way from Vienna to the Dalmatian coast [...]. Instead of publishing these new facts on natural variation, he decided on trying to recreate them in the laboratory as acquired characteristics.

Noticeably, van Alphen and Arntzen doubt the veracity of Kammerer's account. Additionally, they implied that Kammerer's claim that he operated this individual to grow eyes was a fabrication as well, because operating an individual of a subspecies with functional eyes in the described way would neither be necessary nor helpful. Contrary to van Alphen and Arntzen's assertion, however, Kammerer didn't perform such surgical operations on any of his cave salamanders' eyes. In his original publication (Kammerer, 1912), he wrote that during the first 18 months of their life, five cave salamanders were kept in alternating turns in daylight for two weeks and then in dim red light for one week. According to Kammerer, they developed comparably large eyes that were pigmented, but displayed considerable individual variations. Also, their skin was pigmented, but not as intensely as if they had been exposed to continuous sunlight. Another individual was kept in dim red light that was switched off during the night. Supposedly, this animal similarly developed large but unpigmented eyes that resembled eyes of albinos. Its skin remained unpigmented as well. One of the five grey salamanders kept under alternating light conditions was taken to Cambridge in 1923 and photographed (Kammerer, 1924; the Proteus image shown on top of Plate 2 in Koestler, 1971, is the mirror-inverted image of Fig. 39 in Kammerer, 1924).

Hence, van Alphen and Arntzen would have had to suppose that he possessed not one but six (unoperated) individuals of the subspecies of Proteus anguinus with large eyes, preferring not to describe this new remarkable subspecies, but to kill five of the six individuals after five years, using them for a staged publication. Furthermore, according to Kammerer, five of the six individuals of this "black" subspecies were grey and one was almost white (see also Figs 31 to 34 in Kammerer, 1912), and they displayed considerable individual differences with regard to their eyes' development that also appeared uncoordinated and asymmetrical. Nevertheless, Kammerer even predicted that dark cave salamanders with eyes might be discovered in case some individuals were subjected to comparable environmental conditions in natural habitats, and he explicitly stressed that such a discovery would support his experimental results and view on variation and speciation (Kammerer, 1924). ${ }^{6}$ Hence, it can be assumed that if he had really known of the existence of such a subspecies, he would

6 Because of his experimental results, Kammerer regarded species concepts for amphibia quite plastic. Bertz' statement (2009, p. 230) that Kammerer made the "scandalous demand" that his cave salamanders with large eyes should "be classified as a separate species" is erring. By contrast, Kammerer cautioned that such individuals would have been (erroneously) classified as a separate species by others when they would have found them in nature without knowing about their experimental origin and developmental plasticity. 
not have kept it secret, but would rather have placed particular emphasis on its existence either directly using some of the six individuals as proof, or emphasizing its mere existence in later years; for example, in the aforementioned publication (Kammerer, 1924). But he didn't. In fact, all Proteus specimens with dark skin and comparably large eyes found in nature until today belong to the same population that is only known from four sites within a radius of less than $2 \mathrm{~km}^{2}$ (Gorički et al., 2017). On the genetic level, these blackish individuals are so closely related to white individuals living in the same region that they may rather be regarded as local intra-lineage variety than distinct subspecies, thus highlighting the plasticity of this species (Gorički \& Trontelj, 2006; Trontelj et al., 2009).

All in all, the hypothesis that Kammerer's salamanders belonged to a then unknown subspecies with functional eyes remains rather doubtful. This appraisal remains as yet unaffected by van Alphen and Arntzen's (2016) emphasis on negative experimental results reported by Durand (1976). This author stated in a scant sketch of his experiments that he kept (an unspecified number of) European cave salamanders from a single source population under varying light conditions, and they didn't grow unusually large eyes. However, van Alphen and Arntzen themselves stressed that different populations of cave salamanders vary with regard to eye degeneration. In this context, it should at least be noted that nobody else than Noble, who had earlier discovered the ink in the hand of Kammerer's Midwife toad, successfully induced the retention and further growth of eyes in a bind American cave salamander species (Eurycea spelaea) when kept in light (Noble, 1931; fig. 3). He even found an adult specimen with developed eyes in nature, and concluded that eye degeneration is due to absence of light (Noble \& Pope, 1928). Besharse and Brandon (1976) reported that the eyes of Eurycea individuals reared in light had larger eyes as well, but this development was much less pronounced than described by Noble. Unless one is willing to accuse Noble of having staged his reports, the reported differences suggest variability of eye degeneration in Eurycea as well.

Van Alphen and Arntzen moreover argued that Kammerer's alleged experimental protocol for breeding the next generation of Proteus would have lasted a very long time, and they wondered why Kammerer didn't use this argument as a reason for the termination of his Proteus experiments. They stated Kammerer's reason for discontinuing his work was "because the critics would not accept the results anyway" (van Alphen \& Arntzen, 2016, p. 461). The authors provided no source for Kammerer's words. But in any case, their claim constitutes a misleading representation of his arguments. In his main book on the inheritance of acquired characteristics, for example, Kammerer stressed among other theoretical considerations that his critics wouldn't regard his Proteus results as evidence for the acquisition of a new trait but as a mere reactivation of a previously existing trait, caused by the experimental conditions. Clearly, the issue at stake was not the acceptance of his experimental results but their interpretation - and Kammerer explicitly wrote that he didn't want to "lose time" in pursuing such experiments, and that he "resignedly abstained from breeding further generations whose scientific value in every case would have been depreciated" (Kammerer, 1924, p. 75; see especially also Kammerer 1920). ${ }^{7}$ Regarding his experiments with fire salamanders, he also stressed that working with generations of salamanders would be arduous, fraught with unpredictable difficulties, and had the disadvantage of 


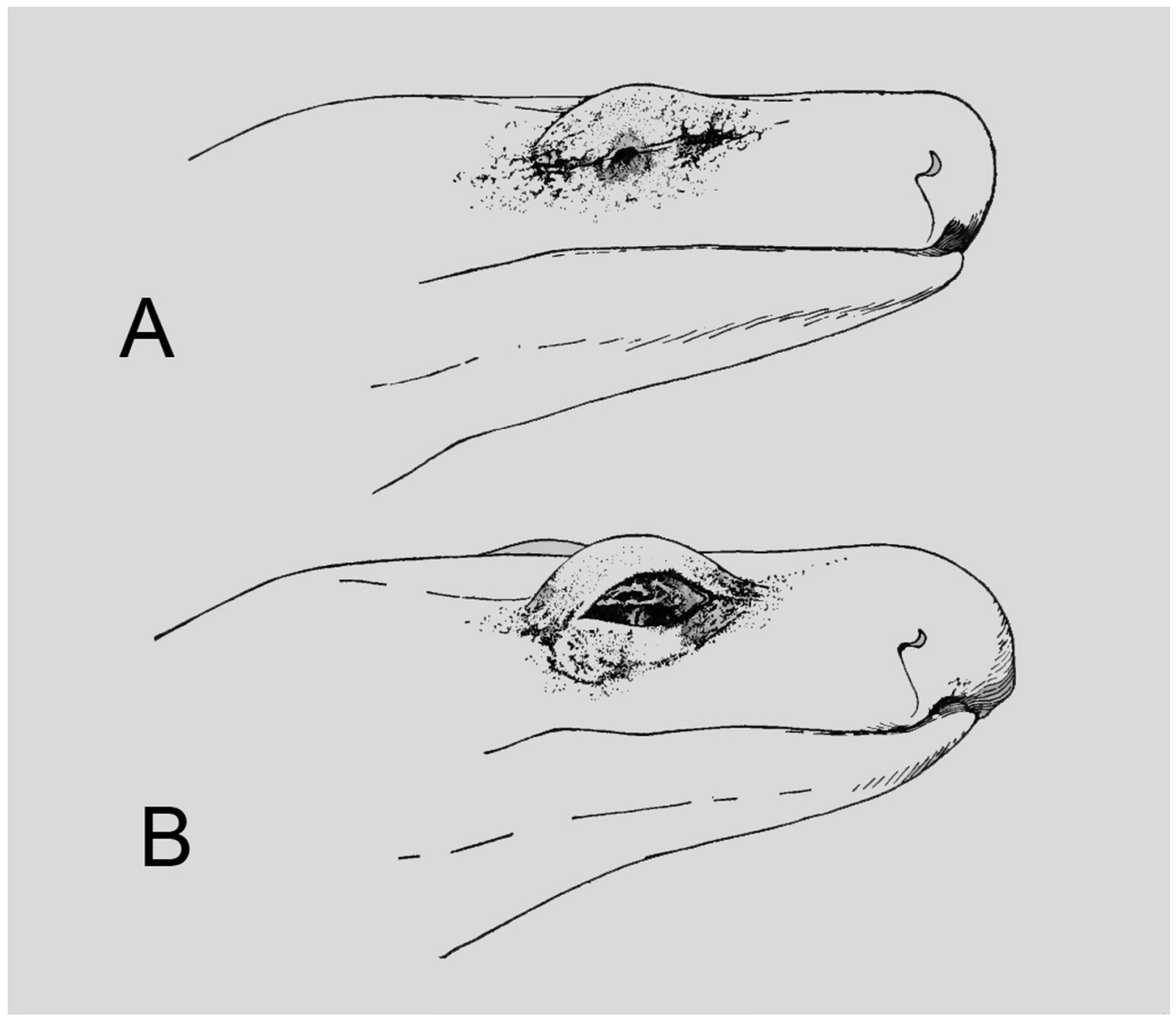

FIGURE 3 A: Head of a blind adult cave salamander Eurycea spelaea reared in the dark for 203 days after the beginning of metamorphosis. B: Head of a specimen reared in light for approximately the same period. It retained and further developed the eyes it possessed as larvae SOURCE: FIG. 32 IN NOBLE, 1931

taking a "very long time" (Kammerer, 1924, p. 120). In addition, Kammerer simply had no individuals of cave salamanders left for future experiments. As mentioned above, he had only six salamanders with significant eyes at his disposal. Because their eyes seemed to have decreased again in relative size in their fifth year, he preferred to preserve most of them for documentation purposes. In September 1911, Kammerer had just one living individual left, and it never showed signs of rut (Kammerer, 1912, p. 433f). Be that as it may, it is obvious that cave salamanders are not the best model organism to study the inheritance of acquired characteristics, simply because they become sexually mature only after about 15 years (Voituron et al., 2011).

7 Ludwig von Bertalanffy, who knew Kammerer well, even speculated that Kammerer's recognition that it will never be possible to provide an unambiguous proof for the inheritance of acquired characteristics was one of the reasons for his suicide (Bertalanffy, 1928, p. 99). 


\section{Breeding water eggs of Midwife toads}

As a final point, I conclude this amendment of the historical record with a comment on van Alphen and Arntzen's second publication about Kammerer which focused on his experiments with Midwife toads (van Alphen \& Arntzen, 2017). The authors highlighted several dubious aspects of Kammerer's description of these experiments, and demonstrated via statistical analyses that the reported distributions of the Mendelian ratios of his amphibian progeny are too good to be genuine. Furthermore, in a section headed "Unexplainable aspects in Kammerer's experiments", the authors referred to four accounts by authors who, in contrast to Kammerer, had no success in breeding eggs of the land-breeding Midwife toad in water because these eggs were infected by mould and died. Van Alphen and Arntzen implied that it would be implausible if not impossible to breed such eggs successfully in water, and thus question these experiments and Kammerer's reports about them. However, two issues should be considered here: First, Kammerer tested substantially larger amounts of eggs than the other authors referred to. The two most recent authors cited by van Alphen and Arntzen, Boulenger (1912) and Nijs (1985), only used spawn carried by two males and 24 eggs, respectively. Second, van Alphen and Arntzen didn't mention that Kammerer placed the eggs in a carefully prepared sterile environment in contrast to the other authors they cited, using boiled and well-aerated water. He stated unmistakably that attempts to breed the eggs in non-sterile conditions would inevitably fail. Hence, at the present state of the affair, the lack of success by the cited authors to breed water eggs of Midwife toads in non-sterile environments doesn't suggest a dishonesty on Kammerer's side, but rather confirms what he found and predicted (Kammerer, 1906, 1914b, 1919b; see Koestler, 1971, for a detailed discussion of these matters). Taking into account that there may be variations regarding egg development due to provenance and individual differences as well as the experimental setting, it might therefore not be impossible to obtain waterbred larvae from Midwife toads: Boulenger (1912) simply put the eggs into normal pond water, and they began to mould after five to six days. Nijs (1985) used tap water in an aerated aquarium, and the eggs developed until the early tailbud stage within 11 days before becoming infected; and Kammerer (1906) reported that in his initial trials, larvae hatched after $13^{-15}$ days.

\section{Final remarks}

As several authors have stressed in the past as well as during recent years, some contents of Kammerer's publications must be treated with caution. Still, similar to the finding that also Gregor Mendel's results were "too good to be genuine", but yet overall correct and worthwhile (Franklin et al., 2008), Kammerer's basic results on the induction of phenotypic adaptions and their heredity might still have been apt. Mere speculations about his work will most likely not contribute significantly to a reliable re-evaluation of its plausibility. But if they are undertaken, it is self-evident that they need to be performed in an impartial and scientifically responsible manner, and require an accurate and careful reading of the original publications to avoid fostering a misleading conception of Kammerer's work and a contortion of the historical record. The frame of the "great filter of time" must be constructed as reliably and realistically as possible. This is of particular relevance for practical research that aims at replicating Kammerer's experiments. It is indispensable to know their exact setting and context to avoid performing experiments that ultimately don't constitute 
adequate replications. The experiments performed by Sanchez et al. (2019) represent a significant step forward, but for exact replications of Kammerer's experiments, they need to run for longer times, and ideally, should include trans-generational research designs (see also Donelson et al., 2018). Nevertheless, lengthy and intricate studies with amphibians and reptiles are difficult to conduct, especially in the present research milieu at universities that is increasingly dominated by temporary research projects and publishing. But perhaps, such experiments might still be possible in cooperation with zoological gardens or other forms of "citizen science", an approach advocated already early by Kammerer (1905). Alternatively, other species that are easier to keep could be used to test the gist of Kammerer's claims regarding, for example, the inheritance of colour adaptions. As mentioned earlier, he also exposed slugs as well as snails to different environmental colours, and reported respective colour changes. However, he didn't report whether they produced offspring (Kammerer, 1911). It might be worthwhile to repeat such experiments. In fact, Kammerer's colleague Leonore Brecher kept caterpillars of butterflies in differently coloured environments, and their chrysalises displayed colour adaptions that seemed heritable (Brecher, 1922). Independently of her work, Bernhard Dürken also found that environmentally induced variations of pupal colours were heritable (Dürken, 1923). Given that these effects must have been carried over through the life of the imagines, these are remarkable reports. In order to expand our knowledge about non-genetic inheritance, also Kammerer's experiments with Ciona might stimulate researchers to assess the heritability of experimentally induced modifications in organisms that are able to regenerate their germ line. Although Kammerer's Ciona experiments could not be replicated until today (Jeffery, 2015), ascidians including Ciona (Kürn et al., 2011; Jeffery, 2015) might still be suited, but also other organisms such as planaria and plants.

Hence, whatever the ultimate value of Kammerer's publications may be, they open the door to studying a fascinating but largely forgotten historical niche of biological experimentation and theory building. The older literature on the inheritance of acquired characteristics contains numerous intriguing reports by other authors than Kammerer, who cannot be regarded as the discoverer of epigenetic inheritance (Vargas, 2009), anyway (Gliboff, 2010). In fact, if some results of the other reported experiments were genuine and could be replicated successfully, they might stimulate and advance modern research into epigenetics just as much as Kammerer's. Introductory overviews on the state of the art of research into the inheritance of acquired characteristics performed around Kammerer's time are provided by e.g., Przibram (1910b), Semon (1912), and Kammerer (1924).

\section{Acknowledgements}

The article processing charge was funded by the Baden-Wuerttemberg Ministry of Science, Research and Art and the University of Freiburg in the funding programme Open Access Publishing.

\section{References}

Anonymous (1926) Paul Kammerer's letter to the Moscow Academy. Science, 64, 493-494.

Badyaev, A.V. \& Uller, T. (2009) Parental effects in ecology and evolution: Mechanisms, processes and implications. Phil. Trans. R. Soc. B., 364, 1169-1177. 
Baedke, J. (2019) O organism, where art thou? Old and new challenges for organism-centered biology.J. Hist. Biol., 52, 293-324.

Balagová, M. \& Uhrin, M. (2015) Sex-biased dorsal spotted patterns in the fire salamander (Salamandra salamandra). Salamandra, 51, 12-18.

Bateson, W. (1913) Problems of genetics. Yale University Press, New Haven, CT.

Baur, E. (1914a) Einführung in die experimentelle Vererbungslehre. Borntraeger, Berlin.

Baur, E. (1914b) Bemerkungen zu Kammerers Abhandlung: Vererbung erzwungener Farbänderungen. Arch. Entwicklung. Org., 38, 682-684.

Baur, E.(1917) Referat:Kammerer, P.1915. Allgemeine Biologie. Z. Indukt. Abstamm. Ver., 17, 162-163.

Bedriaga, J. v. (1897) Die Lurchfauna Europa's. II. Urodela. Schwanzlurche. Bull. Soc. Imp. Nat. Moscou, 10, 187-322, 363-476, 575-76o.

Bertalanffy, L. v. (1928) Kritische Theorie der Formbildung. Borntraeger, Berlin.

Bertalanffy, L. v. (1970) Chance or law. In:A. Koestler \& J.R. Smythies (Eds) Beyond reductionism, pp. 56-76. Macmillan, New York, NY.

Bertz, P. (2009) The eyes of the olms. Hist. Phil. Life Sci., 31, 215-239.

Besharse, J. \& Brandon, R.A. (1976) Effects of continuous light and darkness on the eyes of the troglobitic salamander Typhlotriton spelaeus. J. Morphol., 149, 527-546.

Boulenger, E.G. (1921) Experiments on colourchanges of the spotted salamander (Salamandra maculosa), conducted in the Society's gardens. P. Zool. Soc. London, 1921, 99-102.

Boulenger, G.A. (1912) Observation sur l'accouplement et la ponte de l'Alyte accoucheur, Alytes obstetricans. B. Cl. Sci. Ac. Roy. Belg., 2, 570-579.

Boulenger, G.A. (1917) Remarks on the Midwife toad (Alytes obstetricans), with reference to Dr. P. Kammerer's publications. Ann. Mag. Nat. Hist., 20, 173-184.

Brecher, L. (1922) Nachwirkung von Lichtmodifikationen in Finsternis. (Die
Puppenfärbungen des Kohlweißlings, Pieris brassicae IX und die Puppenfärbungen der Vanessiden III). Anzeiger, 59, 228-230.

Burggren, W. (2016) Epigenetic inheritance and its role in evolutionary biology: Re-evaluation and new perspectives. Biology, 5, 24.

Cabej, N.R. (2019) Epigenetic principles of evolution. Academic Press, London.

Coen, D.C. (2006) Living precisely in fin-de-siècle Vienna. J. Hist. Biol., 39, 493-523.

Danchin, E., Pocheville, A., Rey, O., Pujol, B. \& Blanchet, S. (2019) Epigenetically facilitated mutational assimilation: Epigenetics as a hub within the inclusive evolutionary synthesis. Biol. Rev., 94, 259-282.

Darwin, C. (1859) On the origin of species by means of natural selection. Murray, London.

Darwin, C. (1868) Variation of animals and plants under domestication (2 vols.). Murray, London.

Detto, C. (1904) Die Theorie der direkten Anpassung und ihre Bedeutung für das Anpassungs- und Deszendenzproblem. Fischer, Jena.

Donelson, J.M., Salinas, S., Philip L., Munday, P.L. \& Shama, L.N.S. 2018. Transgenerational plasticity and climate change experiments: Where do we go from here? Glob. Change Biol., 24, 13-34.

Driesch, H. (1903) Die „Seele“ als elementarer Naturfaktor: Studien über die Bewegungen der Organismen. Engelmann, Leipzig.

Driesch, H. (1908) The science and philosophy of the organism (2 vols.). Black, London.

Durand, J.P. (1976) Ocular development and involution in the European cave salamander, Proteus anguinus Laurenti. Biol. Bull., 151, 450-466.

Dürken, B. (1923) Über die Wirkung farbigen Lichtes auf die Puppen des Kohlweißlings (Pieris brassicae) und das Verhalten der Nachkommen. Ein Beitrag zur Frage der somatischen Induktion. Arch. Mikrosk. Anat. En., 99, 222-389.

Feichtinger,J.(2017)The Biologische Versuchsanstalt in historical context.In:G.B.Müller(Ed) Vivarium. Experimental, quantitative, and theoretical biology at Vienna's Biologische Versuchsanstalt, pp. 53-73. MIT Press, Cambridge, MA. 
Fernandez, P.J. Jr. \& Collins, J.P. (1988) Effect of environment and ontogeny on color pattern variation in Arizona tiger salamanders (Ambystoma tigrinum nebulosum Hallowell). Copeia, 4, 928-938.

Flemming, W. (1897) Weitere Bemerkungen über den Einfluss von Licht und Temperatur auf die Färbung der Salamanderlarve. Arch. Mikro. Anat. Entw., 48, 69o-692.

Franklin, A., Edwards, A.W.F., Fairbanks, D.J., Hartl, D.L. \& Seidenfeld, T. (2008) Ending the MendelFisher Controversy. University of Pittsburgh Press, Pittsburgh, PA.

Frisch, K. v. (1920) Über den Einfluß der Bodenfarbe auf die Fleckenzeichnung des Feuersalamanders. Biol. Zbl., 40, 390-414.

Gliboff, S. (2005) 'Protoplasm...is soft wax in our hands': Paul Kammerer and the art of biological transformation. Endeavour, 29, 162-167.

Gliboff, S. (2006) The case of Paul Kammerer: Evolution and experimentation in the early 2oth century. J. Hist. Biol., 39, 525-536.

Gliboff, S. (2010) Did Paul Kammerer discover epigenetic inheritance? No and why not. J. Exp. Zool. Part B, 314, 616-624.

Gliboff, S. (2011) The Golden Age of Lamarckism, 1866-1926. In: S.G. Gissis \& E. Jablonka (Eds) Transformations of Lamarckism. From subtle fluids to molecular biology, pp. 45-55. MIT Press, Cambridge, MA.

Gliboff, S. (2018) Essay review: Cold case reopened. Der Fall Paul Kammerer, Klaus Taschwer. Stud. Hist. Philos. Sci. C, 68-69, 73-77.

Goldschmidt, R. (1956) Portraits from memory. Recollections of a zoologist. University of Washington Press, Seattle, WA.

Gorički, Š., Stanković, D., Snoj, A., Kuntner, M., Jeffery, W.R., Trontelj, P., Pavićević, M., Grizelj, Z., Năpăruş-Aljančič, M. \& Aljančič, G. (2017) Environmental DNA in subterranean biology: rangeextension and taxonomic implications for Proteus. Sci. Rep., 7, 45054.

Gorički, Š. \& Trontelj, P. (2006) Structure and evolution of the mitochondrial control region and flanking sequences in the European cave salamander Proteus anguinus. Gene, 378, 31-41.

Greven, H. (2003) Larviparity and pueriparity. In: D.M. Sever (Ed) Reproductive Biology and Phylogeny of Urodela, pp. 447-475. Science Publishers: Enfield, NH.

Herbst,K.(1919)BeiträgezurEntwicklungsphysiologie der Färbung und Zeichnung der Tiere. I. Der Einfluss gelber, weißer und schwarzer Umgebung auf die Zeichnung von Salamandra maculosa. Abh. Heid. Ak. Wiss., 7, 3-64.

Herbst, C. (1924) Beiträge zur Entwicklungsphysiologie der Färbung und Zeichnung der Tiere. 2. Die Weiterzucht der Tiere in gelber und schwarzer Umgebung. Arch. Mikrosk. Anat. En., 102, 130-167.

Herbst, C. (1927) Beiträge zur Entwicklungsphysiologie der Färbung und Zeichnung der Tiere. IV. Kritische Bemerkungen zu der Arbeit von MacBride „Influence of the colour of the background on the colour of the skin of Salamandra maculosa". Roux Arch. Dev. Biol., 112, 59-6o.

Herbst, C. \& Ascher, F. (1927) Beiträge zur Entwicklungsphysiologie der Färbung und Zeichnung der Tiere. III. Der Einfluss der Beleuchtung von unten auf das Farbkleid des Feuersalamanders. Roux Arch. Dev. Biol., 112, 1-59. Herrel, A., Huyghe, K., Vanhooydonck, B., Backeljau, T., Breugelmans, K., Grbac, I., van Damme, R. \& Irschick, D.J. (2008) Rapid largescale evolutionary divergence in morphology and performance associated with exploitation of a different dietary resource. Proc. Natl. Acad. Sci. U.S.A., 105, 4792-4795.

Hirschmüller, A. (1991) Paul Kammerer und die Vererbung erworbener Eigenschaften. Medizinhist. J., 26, 26-77.

Jablonka, E. \& Lamb, M.J. (2006) Evolution in four dimensions. Miт Press, Cambridge, MA.

Jablonka, E. \& Lamb, M.J. (2020) Inheritance systems and the extended evolutionary synthesis. Cambridge University Press, Cambridge. 
Jablonka, E. \& Raz, G. (2009) Transgenerational epigenetic inheritance: Prevalence, mechanisms, and implications for the study of heredity and evolution. Q. Rev. Biol., 84, 131-176.

Jeffery, W.R. (2015) Closing the wounds: One hundred and twenty five years of regenerative biology in the ascidian Ciona intestinalis. Genesis, 53, 48-65.

Jollos, V. (1921) Experimentelle Protistenstudien. Fischer, Jena.

Kammerer, P. (1904) Beitrag zur Erkenntnis der Verwandtschaftsverhältnisse von Salamandra atra und maculosa. Arch. Entwicklung. Org., 17, $165^{-264 .}$

Kammerer, P. (1905) Die Aquarien- und Terrarienkunde in ihrem Verhältnis zur modernen Biologie. Blätter für Aquarien- und Terrarienkunde, 16, 83-86, 94-96.

Kammerer,P.(1906) Experimentelle Veränderung der Fortpflanzungstätigkeit bei Geburtshelferkröte (Alytes obstetricans) und Laubfrosch (Hyla arborea). Arch. Entwicklung. Org., 22, 48-140.

Kammerer, P. (1907a) Regeneration sekundärer Sexualcharaktere bei den Amphibien. Arch. Entwicklung. Org., 25, 82-124.

Kammerer, P. (1907b) Regeneration des Dipterenflügels beim Imago. Arch. Entwicklung. Org., 25, 349-36o.

Kammerer, P. (1907c) Symbiose zwischen Libellenlarve und Fadenalge. Arch. Entwicklung. Org., 25, 52-81.

Kammerer, P. (1907d) Vererbung erzwungener Fortpflanzungsanpassungen. I. und II. Mitteilung: Die Nachkommen der spätgeborenen Salamandra maculosa und der frühgeborenen Salamandra atra. Arch. Entwicklung. Org., 25, 7-51.

Kammerer, P. (1909) Vererbung erzwungener Fortpflanzungsanpassungen. III. Mitteilung: Die Nachkommen der nicht brutpflegenden Alytes obstetricans. Arch. Entwicklung. Org., 28, 447-545.

Kammerer, P. (1910a) Die Wirkung äußerer Lebensbedingungen auf die organischeVariation im Lichte der experimentellen Morphologie. Arch. Entwicklung. Org., 30, 379-408.
Kammerer, P. (1910b) Vererbung erzwungener Farbänderungen. I. und II. Mitteilung: Induktion von weiblichen Dimorphismus bei Lacerta muralis, von männlichem Dimorphismus bei Lacerta fiumana. Arch. Entwicklung. Org., 29, $45^{6-498 .}$

Kammerer, P. (1911) Direkt induzierte Farbanpassungen und deren Vererbung. Vortrag, gehalten dem viII. Internationalen Zoologenkongresse zu Graz. Z. Indukt. Abstamm. Ver., 4, 279-288.

Kammerer,P.(1912)ExperimenteüberFortpflanzung, Farbe, Augen und Körperreduction bei Proteus anguinus Laur. Arch. Entwicklung. Org., 33, 349-461.

Kammerer, P. (1913a) Genossenschaften von Lebewesen auf Grund gegenseitiger Vorteile. Strecker und Schröder, Stuttgart.

Kammerer, P. (1913b) Vererbung erzwungener Farbveränderungen, IV. Mitteilung: Das Farbkleid des Feuersalamanders (Salamandra maculosa Laurenti) in seiner Abhängigkeit von der Umwelt. Arch. Entwicklung. Org., 36, 4-193.

Kammerer, P. (1914a) Aufklärung zu vorstehenden Bemerkungen des Herrn Professor Baur. Arch. Entwicklung. Org., 38, 684.

Kammerer, P. (1914b) Bemerkungen zum Laichgeschäft und der Brutpflege bei der Geburtshelferkröte (Alytes obstetricans). Blätter für Aquarien- und Terrarienkunde, 25, 259-261.

Kammerer, P. (1915) Allgemeine Biologie. Deutsche Verlags-Anstalt, Stuttgart.

Kammerer, P. (1919a) Das Gesetz der Serie. Deutsche Verlags-Anstalt, Stuttgart.

Kammerer, P. (1919b) Vererbung erzwungener Formveränderungen. I. Mitteilung: Brunftschwiele der Alytes-Männchen aus „Wassereiern“, zugleich:Vererbung erzwungener Fortpflanzungsanpassungen, V. Mitteilung. Arch. Entwicklung. Org., 45, 323-370.

Kammerer, P. (1920) Dunkeltiere im Licht und Lichttiere im Dunkel. Naturwissenschaften, 13(2), 28-35. 
Kammerer, P. (1923a) Breeding experiments on the inheritance of acquired characteristisc. Nature, 111, 637-640.

Kammerer, P. (1923b) Experiments on Ciona and Alytes. Nature, 112, 826-827.

Kammerer, P. (1924) The inheritance of acquired characteristics. Boni and Liveright, New York, NY.

Kammerer, P.(1926) Der Artenwandel auf Inseln und seine Ursachen, ermittelt durch Vergleich und Versuch an den Eidechsen der dalmatinischen Inseln. Deuticke, Wien.

Kammerer, Paul. (1922) Die Zeichnung von Salamandra maculosa im durchfallenden farbigen Licht. Arch. Entwicklung. Org., 50, 79-107.

Klewen, R. (1985) Untersuchungen zur Ökologie und Populationsbiologie des Feuersalamanders (Salamandra salamandra terrestris LACEPÉDÈ 1788) an einer isolierten Population im Kreise. Paderborn. Abhandlungen aus dem Westfälischen Museum für Naturkunde, 47(1), 1-51.

Koestler, A. (1971) The case of the Midwife toad. Hutchinson, London.

Kürn, U., Rendulic, S., Tiozzo, S. \& Lauzon, R.J. (2011) Asexual propagation and regeneration in colonial ascidians. Biol. Bull., 221, 43-61.

Laland, K.N., Uller, T., Feldman, M.W., Sterelny, K., Müller, G.B., Moczek, A., Jablonka, E. \& OdlingSmee, J. (2015) The extended evolutionary synthesis: Its structure, assumptions and predictions. Proc. Royal Soc. B, 282, 20151019.

Lamarck, J.-B. de (1809) Philosophie zoologique. Dentu, Paris.

Liu, Y.-S. (2011) Inheritance of acquired characters in animals: A historical overview, further evidence and mechanistic explanations. Ital. J. Zool., 78, 410-417.

Logan, C.A. (2007) Overheated rats, race, and the double gland: Paul Kammerer, endocrinology and the problem of somatic induction. J. Hist. Biol., 40, 683-725.

Ma, L., Sun, B.J, Li, S.-R., Sha, W., Du, W.-G. (2014) Maternal thermal environment induces plastic responses in the reproductive life history of oviparous lizards. Physiol. Biochem. Zool., 87, 677-683.

MacBride, E.W. (1925) The influence of the colour of the background on the colour of the skin of Salamandra maculosa. P. Zool. Soc. London, 1925, 983-993.

Mahler-Werfel, A. (1960) Mein Leben. Fischer, Frankfurt am Main.

Mayr, E. (1982) The growth of biological thought. Belknap Press of Harvard University Press, Cambridge, MA.

Megušar, F. (1914) Über den Einfluss äußerer Faktoren und über Vererbung bei Krustazeen, Insekten, Mollusken und Amphibien. Ver. Ges. D. N., 85, 717-719.

Müller, G.B. (2017) The substance of form. In: G.B. Müller (Ed) Vivarium. Experimental, quantitative, and theoretical biology at Vienna's Biologische Versuchsanstalt, pp. 135-163. MIT Press, Cambridge, MA.

Nahm,M. (2O21) Ganzheitsbiologische Strömungen im Umfeld der Philosophie von Hans Driesch. In: S. Krall, M. Nahm \& H.-P. Waldrich (Eds) Hinter der Materie. Hans Driesch und die Natur des Lebens, pp. 143-201. Graue Edition, Zug.

Najbar, A., Konowalik, A., Najbar, B. \& Ogielska, M. (2018) Yellow patterns polymorphism of the fire salamander Salamandra salamandra in Poland. Acta Herpetol., 13, 101-108.

Nijs, J. (1985) Enkele ervaringen met de eieren van de vroedmeesterpad, Alytes obstetricans. Lacerta, 43, 82-83.

Noble, D. (2017) Evolution viewed from physics, physiology and medicine. Interface Focus, 7, 20160159 .

Noble, G.K. (1926) Kammerer's Alytes. Nature, 118, 209-210.

Noble, G.K. (1931) The biology of the amphibia. McGraw-Hill, New York, NY.

Noble, G.K. \& Pope, S.H. (1928) The effect of light on the eyes, pigmentation, and behavior of the cave salamander, Typhlotriton. Anat. Rec., 41, 21.

Paredes, U., Radersma, R., Cannell, N., While, G.M. \& Uller, T. (2016) Low incubation 
temperature induces DNA hypomethylation in lizard brains. J. Exp. Zool. A Ecol. Genet. Physiol., 325, 390-395.

Pauly, A. (1905) Darwinismus und Lamarckismus: Entwurf einer psychophysischen Teleologie. Reinhard, München.

Pennisi, E. (2009) The case of the Midwife toad: Fraud or epigenetics? Science, 325, 1194-1195.

Polo-Cavia, N. \& Gomez-Mestre, I. (2017) Pigmentation plasticity enhances crypsis in larval newts: Associated metabolic cost and background choice behaviour. Sci. Rep.-UK, 7 , 39739 .

Przibram, H. (1910a) Übertragung erworbener Eigenschaften bei Säugetieren: Versuche mit Hitze-Ratten. Ver. Ges. D. N., 81, 179-180.

Przibram, H. (1910b) Experimental-Zoologie. 3. Phylogenese inklusive Heredität. Deuticke, Leipzig.

Przibram, H. (1917) Dr. Franz Megusar. Arch. Entwicklung. Org., 43, 222.

Przibram, H. (1925) Die Schwanzlänge der Nachkommen temperaturmodifizierter Ratten, Mus (Epimus) decumanus All. und M. (E.) rattus L. Arch. Mikrosk. Anat. En., 104, 548-610.

Przibram, H. (1926) Paul Kammerer als Biologe. Monistische Monatshefte, 11, 401-405.

Przibram, H., with Dembowski,J. (1922) Der Einfluß gelber und schwarzer Umgebung der Larve auf die Fleckenzeichnung des Vollmolches von Salamandra maculosa Laur. forma typica. Arch. Entwicklung. Org., 50, 108-146.

Richards, E.J. (2006) Inherited epigenetic variation - revisiting soft inheritance. Nat. Rev. Genet., 7, 395-401.

Sanchez, E., Pröhl, H., Lüddecke, T., Schulz, S., Steinfartz, S. \& Vences, M. (2019) The conspicuous postmetamorphic coloration of fire salamanders, but not their toxicity, is affected by larval background albedo. J. Exp. Zool. Part B, 332, 26-35.

Schrey, A.W., Robbins, T.R., Lee, J., Dukes, D.W., Ragsdale, A.K., Thawley, C.J. \& Langkilde, T. (2016) Epigenetic response to environmental change: DNA methylation varies with invasion status. Environ. Epigenet., 2, 1-5.

Šećerov, S. (1914) Über das Farbkleid von Feuersalamandern, deren Larven auf gelbem oder schwarzem Untergrunde gezogen waren. Biol. Zbl., 34, 339-344.

Semon, R. (1912) Das Problem der Vererbung "erworbener Eigenschaften". Engelmann, Leipzig.

Shine, R., \& Downes, S.J. (1999) Can pregnant lizards adjust their offspring phenotypes to environmental conditions? Oecologia, 119, 1-8. Smith, T., Martin, M.D., Nguyen, M. \& Mendelson, T.C. (2016) Epigenetic divergence as a potential first step in darter speciation. Mol. Ecol., 25, 1883-1894.

Steinach, E. \& Kammerer, P. (1920) Klima und Mannbarkeit. Arch. Entwicklung. Org., 46, 391-458.

Sun, B.J., Wang, Y., Wang, Y., Lu, H.L. \& Du, W.G. (2018) Anticipatory parental effects in a subtropical lizard in response to experimental warming. Front. Zool., 15, 51.

Svardal, H. (2010) Can epigenetics solve the case of the Midwife toad? - a comment on Vargas. J. Exp. Zool. Part B, 314, 625-628.

Taschwer, K. (2016) Der Fall Paul Kammerer. Das abenteuerliche Leben des umstrittensten Biologen seiner Zeit. München, Carl Hanser.

Trontelj, P., Douady, C.J., Fišer, C., Gibert, J., Gorički, Š., Lefébure, T., Sket, B. \& Zakšek, V. (2009) A molecular test for cryptic diversity in ground water: how large are the ranges of macrostygobionts? Freshw. Biol., 54, 727-744.

van Alphen, J.J.M. \& Arntzen, J.W. (2016) Paul Kammerer and the inheritance of acquired characteristics. Contrib. Zool., 85, 457-470.

van Alphen, J.J.M. \& Arntzen, J.W. (2017) The case of the midwife toad revisited. Contrib. Zool., 86 261-272

Vargas, A.O. (2009) Did Paul Kammerer discover epigenetic inheritance? A modern look at the controversial Midwife toad experiments. J. Exp. Zool. Part B, 312, 667-678. 
Vargas, A.O., Krabichler, Q. \& Guerrero-Bosagna, C. (2017) An epigenetic perspective on the midwife toad experiments of Paul Kammerer.J. Exp. Zool. Part B, 328, 179-192.

Vervust, B., Grbac, I. \& van Damme, R. (2007) Differences in morphology, performance and behaviour between recently diverged populations of Podarcis sicula mirror differences in predation pressure. Oikos, 116, 1343-1352.

Voituron, Y., Fraipont, M. de, Issartel, J., Guillaume, O. \& Clobert, J. (2011) Extreme lifespan of the human fish (Proteus anguinus): A challenge for ageing mechanisms. Biol. Lett., 7, 105-107.

Weismann, A. (1892) Aufsätze über Vererbung und verwandte biologische Fragen. Fischer, Jena.

Weismann,A.(1904)VorträgeüberDeszendenztheorie (2 vols.). Fischer, Jena.
Werner, F. (1915) Einige Bemerkungen zu den Salamander-Experimenten von Šećerov und Kammerer. Biol. Zbl., 35, 176-181.

West-Eberhard, M.-J. (2003) Developmental plasticity and evolution. Oxford University Press, New York, NY:

Woltereck, R. (1932) Grundzüge einer allgemeinen Biologie. Fischer, Jena.

RECEIVED: 24 NOVEMBER 2O2O | REVISED

AND ACCEPTED: 17 MARCH 2021

EDITOR: R. VONK 